\title{
DETECTION OF NEOSPORA CANINUM AND COXIELLA BURNETII ANTIBODIES IN MILK AND SERUM OF INFECTED DAIRY CATTLE
}

\author{
GERGES, A.A. ${ }^{1}$; MONA, SOBHY ${ }^{1}$; FATHI, A. ${ }^{2}$; HAMS, M.A. MOHAMED ${ }^{3}$; \\ ABOU-GAZIA, KH.A. ${ }^{1}$ and MOHAMED, H.F. ${ }^{1}$ \\ ${ }^{1}$ Department of Reproductive Diseases, ARRI, ARC, Giza, Egypt \\ ${ }^{2}$ Unit of Immunity, ARRI, ARC, Giza, Egypt. \\ ${ }^{3}$ Dept. of Microbiology, Fac. of Vet. Med. SVU, Qena, Egypt
}

Received: 21 May 2018; Accepted: 25 June 2018

\begin{abstract}
Coxiella burnetii and Neospora caninum are frequent infectious causes of decreased reproductive outcomes in cattle around the world. So our study aimed to assess the performance of IgG-ELISA for diagnosis of $N$. caninum and C. burnetii and compare the sensitivity of ELISA and IFA in detection IgG to C.burnetii phase II ,to achieve these, a total of 200 samples including milk and serum samples (100 for each) were collected from 100 dairy cattle suffering from infertility and abortion during the period from January to December 2017 in four governorates of upper Egypt, these samples were transferred to laboratory for serological examination. The results revealed that N.caninum antibodies were detected in $29 \%$ of serum samples and $10 \%$ of milk samples while C.burnetii antibodies were detected in $34 \%$ and $17 \%$ of serum and milk samples respectively. The IgGELISA of both N.caninum and C.burnetii were detected in the same serum and milk samples with percentage $14 \%$ and $4 \%$ respectively, amid dairy cattle in 4 governorates of upper Egypt. IgM-IFA indicated the acute infection of C.burnetii in $11 \%$ and $4 \%$ of serum and milk samples while chronic infection (IgG-IFA) was detected in $19 \%$ of serum samples and $8 \%$ of milk samples. The comparison between sensitivity of ELISA and IFA in detection of IGg for C.burnetii phase II showed that ELISA was more sensitive and excellent diagnostic method for C.burnetii infection.
\end{abstract}

Key words: Serum, Milk, N. caninum, C. burnetii, ELISA, IFA

\section{INTRODUCTION}

The rate of reproductive problems in cattle have been increasing over years and causes many economic problems in the bovine industry and public health which represented a standpoint because of their zoonotic importance, a number of infectious agents for instance, bacteria, viral, fungus and parasitic are recognized to have a direct impact on reproductive health of cattle (Yoo, 2010).

Neosporosis, caused by the obligate intracellular parasite protozoan called Neospora caninum ( $N$. caninum), it has a highly preference for cattle and dogs as hosts and induces a serious economic losses like abortion, temporary anestrus and less milk production in dairy (Bruhn et al., 2013 and Almería et al., 2017).

$\mathrm{Q}$ fever is a zoonotic and prevalent disease in most

Corresponding author: Dr. HAMS, M.A. MOHAMED

E-mail address: hams.mohamed@ vet.svu.edu.eg

Present address: Dept. of Microbiology, Fac. of Vet. Med. SVU, Qena, Egypt countries of the world, it caused by a gram negative bacteria called Coxiella burnetii (C.burnetii). These bacteria has many hosts include mammals, birds and arthropods like ticks (Angelakis and Raoult 2010).

There are two antigenic forms of $C$. bumetii that are imperative for serologic diagnosis of $\mathrm{Q}$ fever are the phase I (S-LPS) is avirulent form in ticks with smooth lipopolysaccharide and phase II (R-LPS) is avirulent microorganism with rough LPS with whole-cell antigens (Peter et al., 1985).

The shedding of C.burnetii into the environment happens primarily by birth products, especially placenta, are heavily infected with $C$. burnetii also it could be gained from milk and other excreta of infected animals (Schmeer et al., 1987). Coxiella can persist in the environment for long periods and may carried for a long distances through the wind (Kirkan et al., 2008). In cattle, late abortion, mastitis and infertility are the major clinical manifestations related to coxiellosis (Arricau et al., 2003).

Serological methods represent the most widely recognized, broadly available and frequently used tools for the diagnosis of infectious diseases (Garcia- 
perez et al. 2011; An and Ghattof, 2018). These methods are renowned from all other diagnostic methods by providing indirect evidence of infection or exposure by detecting host antibodies reactive against infections.

Enzyme linked immune sorbent assay (ELISA) and immune fluorescence antibody (IFA) generally considered the main serological method for diagnosis the C.burnetii infection (Meekelenkamp et al., 2012 and Anati-Pirouz et al., 2015).

So this study aimed to describe the seroepidemiological situation of $N$. caninum and $C$. burnetii specific antibodies in milk and serum of dairy cattle by using ELISA and IFA in Upper Egypt Governorates

\section{MATERIALS AND METHODS}

\section{1- Samples collection:}

A total of 200 milk and serum samples (100 for each) were collected according the international ethics for animal experiments from 100dairy cattle suffering from infertility and abortion during the period from January to December 2017 in upper Egypt governorates (Table1). Pooled milk and serum samples were collected from the same dairy cattle.

a-Serum samples

Blood samples $(5 \mathrm{ml})$ were collected from the jugular vein of each cow in vacuum tubes without anticoagulant, the serum was decanted according (Peter et al., 1988).

b-Milk samples

each milk sample were centrifuged at $1000 \mathrm{rpm}$ for 10 min, skimmed milk was collected in sterile screw capped bottle and stored at $-20^{\circ} \mathrm{C}$ until examination (Frossling et al., 2003).

NB. All samples were subjected to examination for Brucella infection by using Rose Bengal test (rabid slide agglutination test, ID. Vet Genetics, france) for detection of Brucella antibodies in serum and Milk Ring Test (hematoxylin-stained antigen manufactured by the State Biological Laboratory, Institute of Veterinary Preventive Medicine, Ranipet, India) for detection of Brucella antibodies in milk samples (Alton et al., 1988).

\section{2- Detection of N.caninum antibodies in serum and milk samples by using ELISA test:}

The serum and whey-milk samples were screened for detection of Neospora caninum antibodies (IgG) by commercially available diagnostic indirect ELISA kit in serum, or milk for multispecies (ID. Vet innovative Diagnstics Louis Pasteur. Grabeis, France) using X check software program. All control tests were performed in duplicate. The diluent, wash solution and dilution buffer were primed according to manufacture instruction. The optical density (OD) values of the wells were read with ELISA reader (Titertek Multiskan plus MK II), at a wave length of $450 \mathrm{~nm}$. The attendance of antibody to $N$. caninum was resolute in samples according to $(\mathrm{S} / \mathrm{P})$ ratio for each sample. The positive serum samples have $\mathrm{S} / \mathrm{P}$ ratio $\geq 50$ while positive milk samples have $\mathrm{S} / \mathrm{P}$ ratio $\geq 30$, the incidence of seropositive animals in the governorates was compared using Chi-square test (Analytical Software Package, Statistix version 1.0, 1996).

3-Detection of $C$. burnetii antibodies in serum and milk samples by ELISA and IFA

\section{A-Detection of $C$. burnetii IgG in serum and milk samples by using ELISA test:}

The samples were tested for the existence of anti- $C$. burnetii antibodies (IGg) by ELISA test (ELISA Cox kit, LSI-Laboratories Service International, Lyon, France) according to Yang et al. (2015). The optical density (OD) values of the wells were read with ELISA reader (Titertek Multiskan plus MK II), at a wave length of $450 \mathrm{~nm}$. The $\mathrm{S} / \mathrm{P}$ ratio was categorized in three classes in serum samples: positive $50<\mathrm{S} / \mathrm{P}$ $\leq 80$, doubtful $40<\mathrm{S} / \mathrm{P} \leq 50$ and negatives $\mathrm{S} / \mathrm{P}<40$ were while in milk samples considered positive samples for specific antibodies to $C$. burnetii when $\mathrm{S} / \mathrm{P}>40$, doubtful $30<\mathrm{S} / \mathrm{P} \leq 40$ and negative $\mathrm{S} / \mathrm{P} \leq 30$ according to manufacturer's instructions.

\section{B- Detection of C.burnetii antibodies by indirect Immunofluorescence technique (IFA):}

Milk and serum were tested for $\operatorname{IgM}$ and $\operatorname{IgG}$ antibodies against $C$. burnetii phase II by using slides coated with $C$. burnetii phaseII (VIRCELL,S.L.pza. slides, SPAIN).

\section{1- Detection of IgM}

- serum samples were diluted (1:2) and treated with anti-human IgG sorbent. Different dilution of treated serum were prepared 1:24, 1:48, 1:96 and placed in wells with positive and negative control, after several washing a IgM FITC conjugate solution was added to the wells, The steps were completed according manufacture instructions. The slides were examined under ultraviolet light of fluorescence microscope the reaction is positive when the apple-green fluorescence of coco-bacillary morphology can be observed. The reaction is negative when no fluorescence can be observed.

\section{2-Detection of IgG}

All samples were screened for different dilutions1:32, $1: 64$ and $1: 128$ by adding phosphate buffer saline (PBS). $20 \mu \mathrm{l}$ of each dilution were added to slide wells with control after incubation and several washing, IgG-fluorescein isothiocyanate (FITC) immuneconjugate was added to the wells. The initial dilution of 1:32 was considered as a negative dilution. The IgG phase II titer $>32$ was considered an indicative 
for chronic infection). The slides were examined under ultraviolet light by fluorescence microscope. The reaction is positive when the apple-green fluorescence of coco-bacillary morphology can be observed. The reaction is negative when no fluorescence can be observed.

\section{RESULTS}

All serum and milk samples included in this study were tested for Brucella infection by using rose bengal test and milk ring test. The tested samples showed a negative results.

In the current study, the data illustrated in table (2) and fig (1) showed that the N.caninum antibodies (IgG-ELISA) were detected in $29 \%$ of serum samples and in $10 \%$ of milk samples. The incidence ranged from $28 \%$ to $36 \%$ in serum samples while it ranged from $8 \%$ to $12 \%$ in milk samples collected from cows farms in four governorates of Upper Egypt.

According to results in table (3) and fig (2) chronic infection (IgG for C.burnetii phase II) was cleared in
$34 \%$ of serum samples (IgG titer $>50$ ) and $17 \%$ of milk samples (IgG titer >40), the higher incidence in serum samples was noticed in El-Fayoum governorate while in milk samples, El-Fayoum and Giza were the higher than other governorates.

The results demonstrated in table (4) and fig (3\&4) revealed that recent infection of C.burnetii (IgMIFA)appeared in $11 \%$ of serum samples and $4 \%$ of milk samples while the past infection (IgG-IFA) was showed in $19 \%$ of serum samples and $8 \%$ of milk samples.

The comparative analysis between the results of IgGELISA and these obtained by IFA showed that ELISA is more accurate than IFA in decreasing the false negative results in serum and milk samples (Table 5).

Results in table (6) cleared that both C.burnetii and $N$. caninum antibodies were detected in the same serum and milk samples with percentage $14 \%$ and $4 \%$ among dairy cattle in 4 governorates in Egypt.

\section{Tables}

Table 1: Number of blood and milk samples collected from dairy cattle in different Egyptian governorates.

\begin{tabular}{cccc}
\hline \multirow{2}{*}{ Localities } & \multirow{2}{*}{ No. of samples } & \multicolumn{2}{c}{ Type of samples } \\
\cline { 3 - 4 } & & Blood samples & Milk samples \\
\hline Fayoum & 50 & 25 & 25 \\
\hline Giza & 50 & 25 & 25 \\
\hline Beni-Swief & 50 & 25 & 25 \\
\hline Menia & 50 & 25 & 25 \\
\hline Total & 200 & 100 & 100 \\
\hline
\end{tabular}

Table 2: Incidence of $N$. caninum antibodies in serum and milk samples by using ELISA test.

\begin{tabular}{ccc}
\hline Localities & \multicolumn{2}{c}{ Positive samples for IgG of $N$. caninum } \\
\cline { 2 - 3 } & Serum samples & Milk samples \\
\hline El-Fayoum & $7 / 25(28 \%)$ & $2 / 25(8 \%)$ \\
\hline Giza & $7 / 25(28 \%)$ & $3 / 25(12 \%)$ \\
\hline Beni-Swief & $9 / 25(36 \%)$ & $3 / 25(12 \%)$ \\
\hline El-Menia & $6 / 25(24 \%)$ & $2 / 25(8 \%)$ \\
\hline Total & $29 / 100(29 \%)$ & $10 / 100(10 \%)$ \\
\hline
\end{tabular}

Table 3: Incidence of C.burnetii antibodies in serum and milk samples by using ELISA test.

\begin{tabular}{lcc}
\hline Localities & \multicolumn{2}{c}{ Positive samples for IgG of C. burnetii } \\
\cline { 2 - 3 } & Serum samples & Milk samples \\
\hline El-Fayoum & $12 / 25(48 \%)$ & $5 / 25(20 \%)$ \\
\hline Giza & $7 / 25(28 \%)$ & $5 / 25(20 \%)$ \\
\hline Beni-Swief & $9 / 25(36 \%)$ & $4 / 25(16 \%)$ \\
\hline El-Menia & $6 / 25(24 \%)$ & $3 / 25(12 \%)$ \\
\hline Total & $34 / 100(34 \%)$ & $17 / 100(17 \%)$ \\
\hline
\end{tabular}


Table 4: positive samples for C.burnetii antibodies in milk and serum samples by using IFA test.

\begin{tabular}{ccccc}
\hline Localities & \multicolumn{2}{c}{ IFA test for detection of IgM } & \multicolumn{2}{c}{ IFA test for detection of IgG } \\
\hline & + ve Serum samples & + ve milk samples & + ve Serum samples & + ve milk samples \\
\hline Fayoum & $4 / 25(16 \%)$ & $2 / 25(8 \%)$ & $8 / 25(32 \%)$ & -- \\
\hline Giza & $3 / 25(12 \%)$ & $2 / 25(8 \%)$ & $2 / 25(8 \%)$ & $2 / 25(8 \%)$ \\
\hline Beni-Swief & $2 / 25(8 \%)$ & -- & $6 / 25(24 \%)$ & $3 / 25(12 \%)$ \\
\hline Menia & $2 / 25(8 \%)$ & -- & $3 / 25(12 \%)$ & $3 / 25(12 \%)$ \\
\hline Total & $11 / 100(11 \%)$ & $4 / 100(4 \%)$ & $19 / 100(19 \%)$ & $8 / 100(8 \%)$ \\
\hline
\end{tabular}

Table 5: Comparison between by IFA test and ELISA test indetection IgG of C.burnetii in serum and milk samples.

\begin{tabular}{ccccc}
\hline Localities & \multicolumn{2}{c}{ IIFA test } & \multicolumn{2}{c}{ ELISA test } \\
\hline & + ve Serum samples & + ve milk samples & + ve Serum samples & + ve milk samples \\
\hline El-Fayoum & $8 / 25(32 \%)$ & -- & $12 / 25(48 \%)$ & $5 / 25(20 \%)$ \\
\hline Giza & $2 / 25(8 \%)$ & $2 / 25(8 \%)$ & $7 / 25(28 \%)$ & $5 / 25(20 \%)$ \\
\hline Beni-Swief & $6 / 25(24 \%)$ & $3 / 25(12 \%)$ & $9 / 25(36 \%)$ & $4 / 25(16 \%)$ \\
\hline El-Menia & $3 / 25(12 \%)$ & $3 / 25(12 \%)$ & $6 / 25(24 \%)$ & $3 / 25(12 \%)$ \\
\hline Total & $19 / 100(19 \%)$ & $8 / 100(8 \%)$ & $34 / 100(34 \%)$ & $17 / 100(17 \%)$ \\
\hline
\end{tabular}

Table 6: Positive samples for both C. burnetii and N. caninum antibodies in the same serum and milk samples by using ELISA test.

\begin{tabular}{ccc}
\hline Localities & No. of positive serum samples & No. of positive milk samples \\
\hline Fayoum & $3 / 25(12 \%)$ & $2 / 25(8 \%)$ \\
\hline Giza & $4 / 25(16 \%)$ & -- \\
\hline Beni-Swief & $5 / 25(20 \%)$ & $1 / 25(4 \%)$ \\
\hline Menia & $2 / 25(8 \%)$ & $1 / 25(4 \%)$ \\
\hline Total & $14 / 100(14 \%)$ & $4 / 100(4 \%)$ \\
\hline
\end{tabular}

\section{Figures}

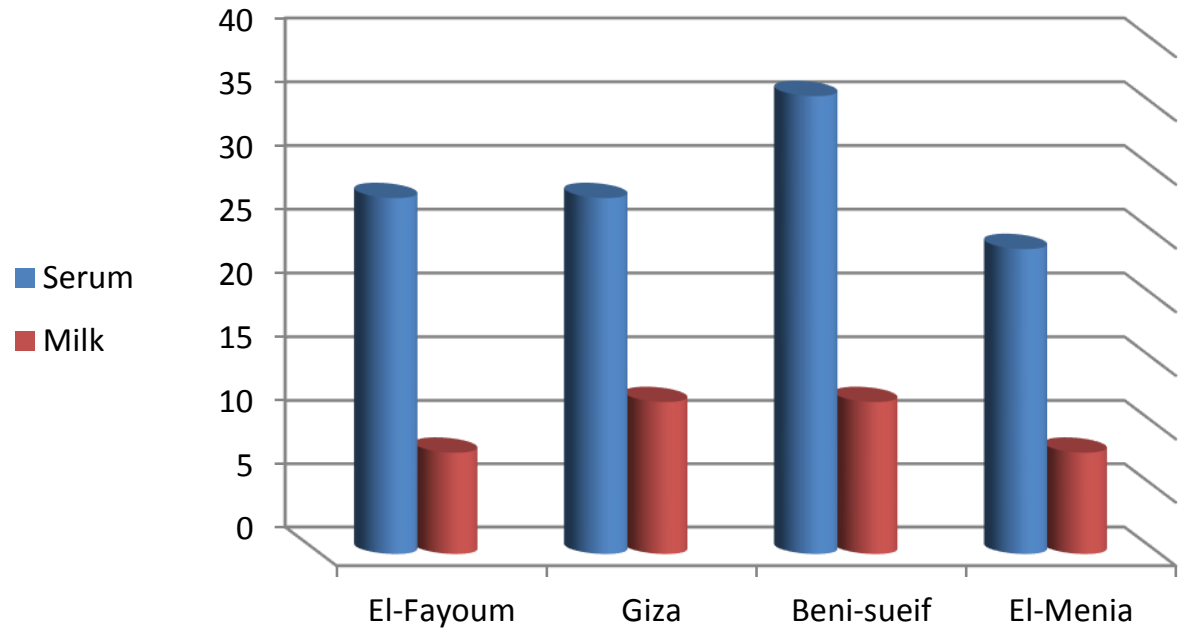

Fig (1): Incidence of N.caninum in serum and milk samples collected from dairy cattle of Upper Egypt governorates by using ELISA 


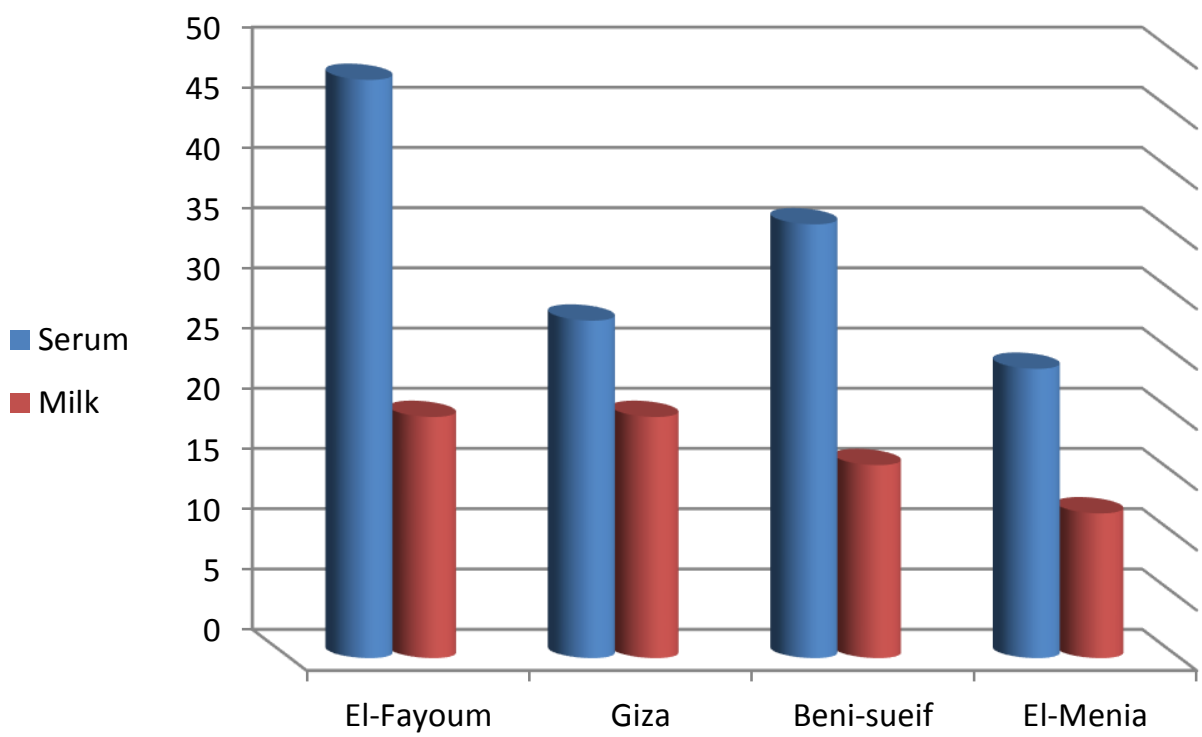

Fig (2): Incidence of C.burnetii in serum and milk samples collected from dairy cattle of Upper Egypt governorates by using ELISA

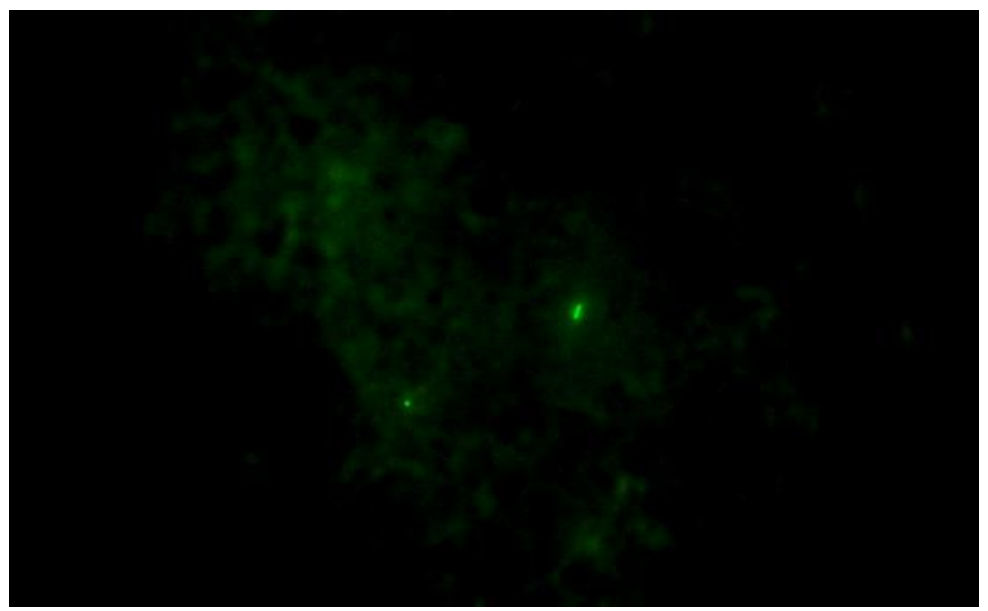

Fig (3): The green fluorescence of IgM to C.burnetii phase II under ultraviolet light at a magnification of 400x by fluorescence microscope

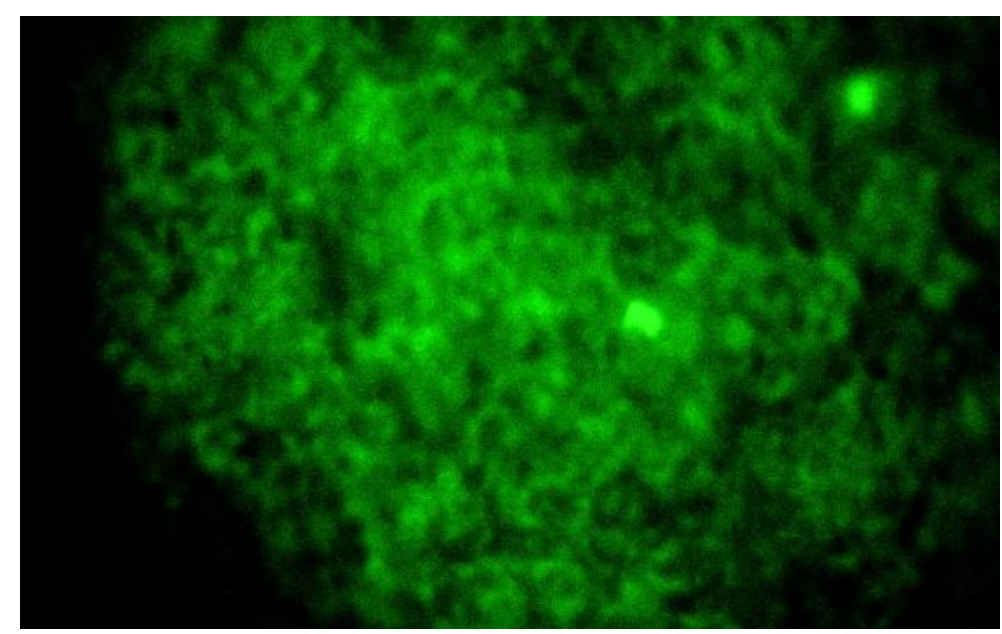

Fig (4): The apple-green fluorescence of $\operatorname{IgG}$ to C.burnetii phase II under ultraviolet light at a magnification of 400x by fluorescence microscope. 


\section{DISCUSSION}

Coxiella burnetii and Neospora caninum are an important reasons of reproductive problems in cattle, they causes a various signs in animals like infertility, early embryonic death, lingering calving seasons, abortion and stillbirth (Anderson, 2007 and Adis et al., 2018).

The serological methods represented the most widely recognized, available and commonly used tools for the diagnosis of infectious diseases by detection specific antibodies (Garcia-Pérez et al., 2011), moreover, the presence or absence of these antibodies in the blood of the host allowing for distinguishing time dependent for acute and chronic infection in serological profile (Guatteo et al., 2011).

Our study demonstrated a different levels of antibodies for N.caninum and C.burnetii in serum and milk samples of upper Egypt governorates but no sample recorded a positivity for Brucella antibodies by rose bangal test and milk ring test, these results in accordance with Softic et al. (2018) who concluded that a high antibodies titer to C.burnetii and $N$. caninum was recorded but Brucella spp. didn't represent a risk in their study.

In this study the incidence of $N$. caninum were recorded in $29 \%$ of serum samples collected from four governorates in Egypt. (Table 2), these results in accordance with Fávero et al. (2017).

The incidence of $N$. caninum antibodies ( $\mathrm{IgG})$ in serum samples were reported in Beni-Sweif (36\%), Giza (28\%), El-Fayoum (28\%) and Menia (24\%) respectively by using ELISA test (Table 2 and fig 1). Lower results were recorded with (Kuruca et al., 2013 and Gerges et al., 2017).

While the incidence of N.caninum were recorded in $10 \%$ of in milk samples (Table 2). Our results in nearly similar with Schares et al. (2003) while the highest rates of infection was recorded in milk (26.66\%) by Pritchard (2001).

Our results showed a differences in incidence of N.caninum antibody in four governorates of upper Egypt, This difference can be imputed to management and therapeutic system, water source, nutrition In addition to contacts of cattle with dogs, (Slapeta et al., 2002).

In recent researches, the epidemiological studies on C. burnetii depend on serological tools in diagnosis (Rousset et al., 2010), because isolation of this pathogen remains time-consuming, risky and requires restricted biosafety level 3 laboratories due to the zoonotic nature of the microorganism (Fournier et al., 1998 and Field et al., 2000).
ELISA is easy to perform and is adapted for automation, on other hand the detection of $\mathrm{IgG}$ give an accurate diagnosis in determination the past infection of C.burnetii (Cowley et al., 1992; Wegdam-Blans et al., 2012).

In our results, the positive antibody titer of $C$. burnetii was determined the chronic infection in $34 \%$ of serum sample and in $17 \%$ of milk samples by using ELISA test (Table 3 and fig.2), higher results were recorded by Hussien et al. (2012) and Dean et al. (2013) on other hand Gwida et al. (2014) recorded a lower incidence of C.burnetii in serum samples collected from upper Egypt farms ranged from 2.9 to $26.7 \%$.

El-Fayoum was recorded a significant increase (P $>0.05)$ for C.burnetii infection in serum and milk samples than other governorates (Table 3 and Fig. 2), these variation in infection rate may be back to several factors like ahost, weather conditions and the type of soil, (Fayer and Reid, 1982), also Adesiyun et al. (1996) reported that epidemiological studies differ in their design, laboratory and statistical analyses, types and number of samples which explained the limitation of the resemblance between results.

The extracellular infectious form of C.burnetii shed in milk, urine, and feces. It was found in high concentration (109 ID50/g) in placental tissue and amniotic fluid (Plummer, 2018). Once a domestic ruminant is infected, C.burnetii can localize in mammary glands, supra-mammary lymph nodes, placenta, and uterus (Agerholm, 2013).

It was noticed in current study that the incidence of C.burnetii in milk samples lower than serum samples although the samples were collected from the same animals (Table 3 and Fig. 2) this may be due the shedding of C.burnetii in milk discontinuous and always occur subsequent to parturition or abortion (Schmeer et al., 1987, Van den Brom et al., 2012 and Agerholm, 2013).

The results illustrated in table (4) and fig $(3 \& 4)$ showed that the recent infection (IgM titre $>1: 24$ ) was recorded in $11 \%$ of serum samples and in $4 \%$ of milk samples while chronic infection (IgG titer $\geq 1: 64$ ) was recorded in $19 \%$ of serum samples and in $8 \%$ of milk samples by using indirect immunofluorcent test (IFA), our results nearly similar to (Sobhy et al. 2016), higher results were obtained by Htwe et al. (1992) who detected antibodies to C. burnetii in $29.5 \%$ of milk samples collected from healthy cattle and $84.3 \%$ of cattle with reproductive diseases in Japan by using IFA.

Our study focus on detection of IgM and IgG titre to phase II C.burnetii antigens by IFA, because the titer of antibodies to this phase reached to high magnitude in short time and persisted for along period, our 
results supported by Uhaa et al. (1994) who compared with $\operatorname{IgM}$ and $\operatorname{IgG}$ to phase I antigens and phase II antigens, he found that IgM and IgG titer to phase II C.burnetii antigens remains for long time circulating in blood of the host in contrary with antibodies to phase I antigens disappearing during the convalescent phases of the illness while antibodies to phase II antigen was observed in acute and chronic infection.

Peacock et al. (1983) found that the raising in IgM and IgG titer to phase II C.burnetii were enough to eliminate the false-positive reactions against related antigens. Also Huebner et al. (1949) found that animals may be responsible for maintenance the chain of infection. However, the ways of transmission still needed further investigation.

Our results showed that the positivity rates of $\mathrm{IgG}$ to C.burnetii in serum and milk samples were detected in $34 \%$ and $17 \%$ by using ELISA while they were $19 \%$ and $8 \%$ by using IFA respectively (Table 5). It was noticed that the sensitivity of ELISA was higher than IFA in detection of IgG to C.burnetii, these results were supported by many previous studies which reported that ELISA, it is critical test to eliminate a variety of false positive and negative results during detection of C.burnetii antibodies (Cowley et al., 1992, Uhaa et al., 1994 and Waritani et al., 2017).

In the present study, both antibodies of $C$. burnetii and $N$. caninum was declared in the same samples by ELISA test, with percentage $14 \%$ in serum samples and $4 \%$ in milk samples (Table 6). Our results supported by García-Ispierto et al. (2010) who concluded the ability of the sharing Coxiella and Neospora antibodies in the same samples. Softic et al. (2018) reported that $C$. burnetii and $N$. caninum are a frequent causes of decreased reproductive consequences and reduced the reproductive performance in cattle worldwide also the higher exposure to C. burnetii and N. caninum in different countries were a highlights need for targeted control of infectious causes of reproductive disorders in dairy cattle of the studied areas.

\section{CONCLUSION}

EILSA is an important tool in diagnosis of $N$. caninum and C.burnetii infection, the elevated altitudes of exposure to C. burnetii and N. caninum in this study need a targeted control for these infectious causes in dairy cattle. So, raising awareness is needed for animal owners, veterinarians, physicians, authorities and control strategies must be applied to protect against infection.

\section{REFERENCES}

Adesiyun, A.A. and Cazabon, E.P. (1996): Seroprevalences of brucellosis. Q fever and toxoplasmosis in slaughter livestock in Trinidad. Rev Elev Med Vet Pays Trop, 49:28-30

Adis, S.; Kassahun, A.; Erik, G.G.; Jacques, G.; Nihad, F. and Eystein, S. (2018): The serostatus of Brucella spp., Chlamydia abortus, Coxiella burnetii and Neospora caninum in cattle in three cantons in Bosnia and Herzegovina. BMC Vet. Res. 14: 40.

Agerholm, J.S. (2013): Coxiella burnetii associated reproductive disorders in domestic animals a critical review. Acta Vet Scand. 2013; 55:13.

Almería, S.; Serrano-Pérez, B. and López-Gatius, F. (2017): Immune response in bovine neosporosis: Protection or contribution to the pathogenesis of abortion. Microb. Pathog. 109: 177-182.

Alton, G.G.; Jones, L.M.; Angus, R.D. and Verger, J.M. (1988): Serological methods. Techniques for the Brucellosis laboratory. Institute National de la Recherche Agronomique. Paris, France.

An, A.A.F. and Ghattof, H.H. (2018): Diagnosis of Neospora caninum using ELIZA and study of histopathological changes in dairy goat in Wasit province: Iraq Journal of Entomology and Zoology Studies; 6(1): 1256-1259.

AnatiPirouz, H.; Mohammadi, G.; Mehrzad, J.; Azizzadeh, M. and Nazem Shirazi, M.H. (2015): Seroepidemiology of Q fever in onehumped camel population in northeast Iran. Tropical animal health and production.; 47(7): 1293-8.

Anderson, M.L. (2007): Infectious causes of bovine abortion during mid- to late-gestation Theriogenology. 68:474-486

Angelakis, E. and Raoult, D. (2010): Q fever. Vet Microbiol 2010; 140:297-309.

Arricau, B.N.; Souriau, A.; Lechopier, P. and Rodolakis, A. (2003): Experimental Coxiella burnetii infection in pregnant goats: Excretion routes. Vet Res; 34:423-433

Bruhn, F.R.; Daher, D.O.; Lopes, E.; Barbieri, J.M.; da Rocha, C.M. and Guimarães, A.M. (2013): Factors associated with seroprevalence of Neospora caninum in dairy cattle in southeastern Brazil. Trop. Anim Health Prod. 45(5): 1093-8.

Cowley, R.; Fernandez, F.; Freemantle, W. and Rutter, D. (1992): Enzyme immunoassay for Q fever: comparison with complement fixation and immunofluorescence tests and dot immunoblotting. J Clin Microbiol 30:2451-5.

Dean, A.S.; Bonfoh, B.; Kulo, A.E.; Boukaya, G.A.; Amidou, M. (2013): Epidemiology of brucellosis and Q fever in linked human and animal populations in northern to go. PLoS 
One, 8:e71501. doi:10.1371/ journal. pone.0071501.

Fávero, J.F.; Aleksandro, S.D.; Gabriela, C.; Gustavo, M.; Luiz, D.B.; João, L.G.; Fernanda, F.V.; Ricardo, E.M. and Lenita, M.S. (2017): Risk factors for Neospora caninum infection in dairy cattle and their possible cause-effect relation for disease. Microbial Pathogenesis. Vol.110, 202-207.

Fayer, R. and Reid, W.M. (1982): Control of coccidiosis. In P.L. Long (Ed.), the Biology of the Coccidia (pp. 453 /487). London: Edward Arnold.

Field, P.R.; Mitchell, J.L.; Santiago, A.; Dickeson, D.J.; Chan, S.W.; Ho, D.W.T.; Murphy, A.M.; Cuzzubbo, A.J. and Devine, P.L. (2000): Comparison of a commercial enzyme-linked immunosorbent assay with immune fluorescence and complement fixation tests for detection of Coxiella burnetii ( $\mathrm{Q}$ fever) immunoglobulin M. J. Clin. Microbiol., 38: 1645-1647.4: 40.

Fournier, P.E.; Marrie, T.J. and Raoult, D. (1998): Diagnosis of Q fever. J Clin Microbiol 1998, 36: 1823-1834.

Frossling, J.; Bonnett, B.; Lindberg, A. and Bjorkman, C. (2003): Validation of Neospora caninum is com ELISA without a gold standard. Prev. Vet. Med. 57:141-53.

Garcia-Pérez, A.L.; Astobiza, I.; Barandika, J.F.; Atxaerandio, R.; Hurtado, A. and Juste, R.A. (2011): Short communication: investigation of Coxiella burnetii occurrence in dairy sheep flocks by bulk-tank milk analysis and antibody level determination. J. Dairy Sci; 92: 15811584.

Gerges, A.A.; Mettias, K.N. and Hassan, H.M. (2017): Surveillance of Neosporosis among different species of animals in different localities in Egypt. J. Egypt. Vet. Med. Assoc. 77, No. 3.545-553.

García-Ispierto, C.; Nogareda, J.L.; Yániz, S.; Almería, D.; Martínez-Bello, N.M.; De Sousa, J.F. Beckers, F. López-Gatius (2010): Neospora caninum and Coxiella burnetii sero positivity are related to endocrine pattern changes during gestation in lactating dairy cows, international journal of animal reproduction 74(2): 212-220

Guatteo, R.; Seegers, H.; Taurel, A.F.; Joly, A. and Beaudeau, F. (2011): Prevalence of Coxiella burnetii infection in domestic ruminants: a critical review. Vet Microbiol, 149: 1-16.

Gwida, M.; El-Ashker, M.; El-Diasty, M.; Engelhardt, C.; Khan, L. and Neubauer, H. (2014): a preliminary study on Q fever in cattle in some Egyptian Governorates BMC $7: 881$.

Htwe, K.K.; Amano, K.; Sugiyama, Y.; Yagami, K.; Minamoto, N.; Hashimoto, A. (1992): Seroepidemiology of Coxiella burnetii in domestic and companion animals in Japan. Vet Rec.;131: 490.

Huebner, R.J.; Jellison, W.L.; Beck, M.D. and Wilcox, F.P. (1949): Q fever studies in southern California. III. Effects of pasturization on survival of Coxiella burnetii in naturally infected milk. Public Health Rep., 64: 499- 511.

Hussien, M.O.; ElFahal, A.M.; Enan, K.A.; Taha, K.M.; Mohammed, M.S.; Salih, D.A.; Mohammadain, S.I.; Saeed, A.A. and ElHussein, A.M. (2012): Seroprevalence of Q fever in Goats of the Sudan. Vet World, 5:394-397.

Kirkan, S.; Kaya, O.; Tekbiyik, S. and Parin, U. (2008): Detection of Coxiella burnetii in cattle by PCR. Tur J Vet Anim Sci, 32: 215-220.

Kuruca, L.; Spasojevic-Kosic, L.; Simin, S.; Savovic, M.; Laus, S. and Lalosevic V. (2013): Neospora caninum antibodies in dairy cows and domestic dogs from Vojvodina, Serbia Parasite, 2013; 20.

Meekelenkamp, JC.; Schneeberger, PM.; Wever, PC. and Leenders, AC. (2012): Comparison of ELISA and indirect immunofluorescent antibody assay detecting Coxiella burnetii IgM phase II for the diagnosis of acute Q fever. Eur J. ClinMicrobiol Infect Dis. 6: 1267-70

Peacock, M.G.; Philip, R.N.; Williams, J.C. and Faulkner, R.S. (1983): Serological evaluation of Q fever in humans: enhanced phase I titers of immunoglobulins $\mathrm{G}$ and $\mathrm{A}$ are diagnostic for $\mathrm{Q}$ fever endocarditis. Infect. Immun. 41: 1089-1098.

Peter, O.; Dupuis, G.; Bee, D.; Luthy, R.; Nicolet, J. and Burgdorfer, W. (1988): Enzyme-linked immunosorbent assay for diagnosis of chronic Q fever. J Clin Microbiol 26: 1978-82.

Peter, O.; Dupuis, G.; Burgdorfer, W. and Peacock, M. (1985): Evaluation of the complement fixation and indirect immunofluorescence tests in the early diagnosis of primary Q fever. Eur. J. Clin. Microbiol. 4: 394-396.

Plummer, P.J. (2018): Overview of Coxiellosis. Merck \& Co., Inc., Kenilworth, NJ, USA.

Pritchard, G. (2001): Milk antibody testing in cattle. In: Praktice.; 23: 542-550

Rousset, E.; Duquesne, V.; Russo, P. and Aubert, M. (2010): Q Fever. In Manual of diagnostic tests and vaccines for terrestrial animals.6th edition. Paris, France: OIE; 2010.

Schares, G.; Barwald, A.; Staubach, C.; Ziller, M.; Kloss, D. and Wurm, R. (2003): Regional distribution of bovine Neospora caninum infection in the German state of Rhineland Palatine modelled by logistic regression. Int. J. for Parasitol. 33: 1631-1640

Schmeer, N.; Muller, P.; Langel, J.; Krauss, H.; Frost, J.W. and Wieda, J. (1987): Q fever vaccines for animals. Zentbl Bakteriol Microbiol Hyg Ser A. 1987; 267: 79-88. 
Slapeta, J.R.; Koudela, B.; Votypka, J.; Modry, D.; Horejs, R. and Lukes J. (2002): Coprodiagnosis of Hammondia heydorni in dogs by PCR based amplification of ITS 1 rRNA: Differentiation from morphologically in distinguishable oocysts of Neospora caninum. Vet. J. 163: 147-154.

Sobhy, M.M.; Kotb, M.H.R.; Attia, E.R.H. and Fath, A. (2016): The prevalence of Coxiella burnetii (Q-fever) as a cause of abortion and infertility among farm animals in some Delta Governorates. Egypt. Vet. Med. Assoc. 76, No. 1: 79-87.

Softic, A.; Asmare, K.; Granquist, E.G.; Godfroid, J.; Fejzic, N. and Skjerve, E. (2018): The serostatus of Brucella spp., Chlamydia abortus, Coxiella burnetii and Neospora caninum in cattle in three cantons in Bosnia and Herzegovina BMC Vet Res.14(1):40.

Uhaa, I.J.; Fishbein, D.B; Olson, J.G.; Rives, C.C.; Waag, D.M. and Williams J.C. (1994): Evaluation of specificity of indirect enzymelinked immune sorbent assay for diagnosis of human Q fever. J. Clin. Microbiol. 6, 15601565 .

Van Den Brom, R.; Van Engelen, E.; Luttikholt, S.; Moll, L.; Van Maanen, K. and Vellema, P.
(2012): Coxiella burnetii in bulk tank milk samples from dairy goat and dairy sheep farms in The Netherlands in 2008. Vet. Rec. 170, 310.

Waritani, T.; Chang, J.; Mckinney, B. and Terato, K. (2017): An ELISA protocol to improve the accuracy and reliability of serological antibody assays MethodsX 4: 153-165

Wegdam-Blans, M.C.A.; Wielders, C.C.H.; Meekelenkamp, J.; Korbeeck, J.M. Herremans, T.; Tjhie, H.T.; Bijlmer, H.A.; Koopmans, M.P.G and Schneeberger, P.M. (2012): Evaluation of commonly used serological tests for detection of Coxiella burnetii Antibodies in well-defined acute and follow-up sera Clin Vaccine Immunol. 7 11101115

Yang, W.S.; Jun H.N.; Nam J.J.; Young C.K.; Seungchan, R.; Jangwon $S$. and Sang $S$. (2015): High-performance photovoltaic perovskite layers fabricated through intramolecular exchange. Science 12, Vol. 348, Issue 6240, pp. 1234-1237.

Yoo, H.S. (2010): Infectious causes of reproductive disorders in cattle. J Reprod Dev. 56: 53-60.

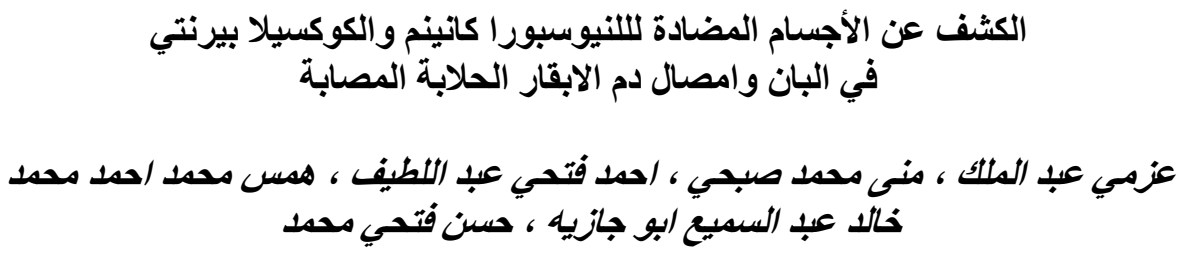

E-mail: hams.mohamed@vet.svu.edu.eg Assiut University web-site: www.aun.edu.eg

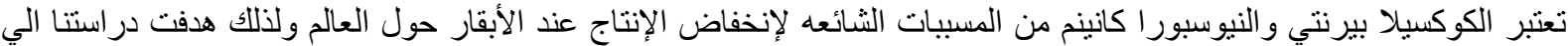

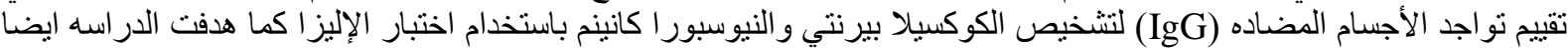

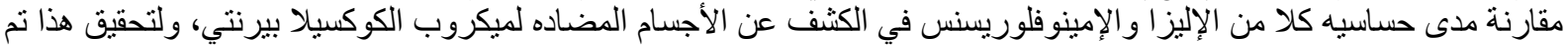

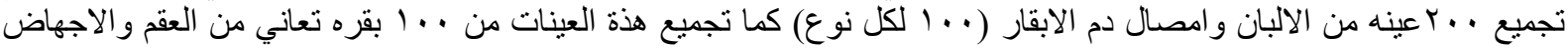

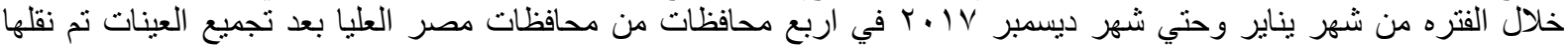

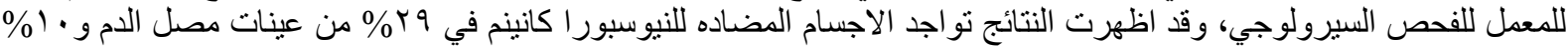

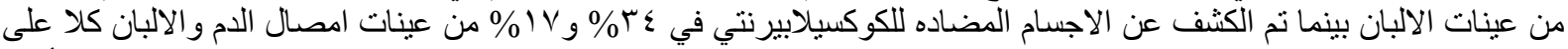

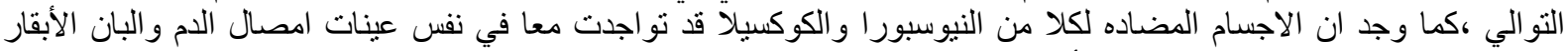

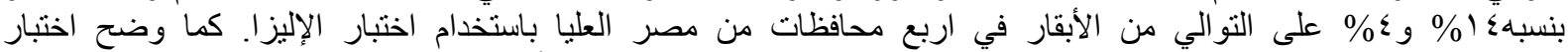

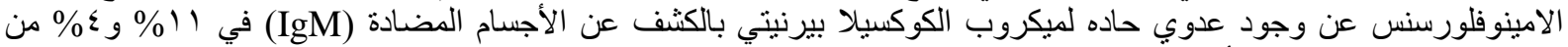

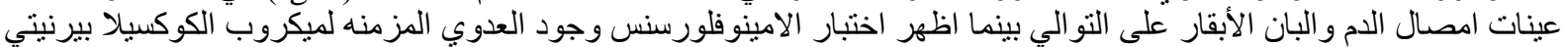

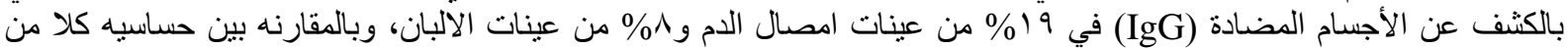
اختبار الإليزا والامينوفلورسنس في الكثف الكف عن الاجسام المضاده (IgG) وجد أن اختبار الإليزا أكثر دقة في تشخيص عدوى 